Pollen Protein, with a Report of the Results of Treatment in the Hayfever Clinic of the New Orleans Charity Hospital," p. 853.

Schatffer, C. W. (Philadeiphia).- "The Municipal Control of Diphtheria," p. 861.

Levbarg, John J. (New York).-“ Intubation for Angioma of the Larynx in a Child of Ten Weeks Old," p. 867.

Swift, W. B. (Boston).- "The Training of the Speech Instructor," p. 869 .

Graham, H. B. (San Francisco)._- "Osteo-sc'erosis of the T'mporal Bone in Chronic Suppuration," p. 872.

KaHN, A. (New York).- "Outlines of a New Instrument to be Used in Skin Grafting in the Radical Mastoid Cavity," p. 875.

This article is illustrated and must be read in the original.

The Laryngoscope, vol. xxix, February, 1919. (Abstracted by J. S. Fraser.)

Lewis, E. R, and Henry Horn.-." Medical Studies on the "Feel of the Airship.' Deaf-mutes and Normals," p. 65.

Cutler, F. E. (New York City).--"Injuries of the Auditory Canal Resulting from Projectiles, with Special Reference to the Separation of the Cartilaginous from the Bony Canal," p. 8.2.

Thomson, Sir Stchair (London, Fingland).- "On the Occisional Preference of a 'Tracheotomic Bronchoscopy to the Per-oral Route," p. 88.

Stricker, O. D. (Atlantic City).- " Report of a Case of Bilateral Acute Suppurative Otitis Media with Symptons of Sinus I'hrombosis," p. 90 . p. 96.

Baum, H. L. (Denver).-- "A New Instrument for Tonsillectomy,"

Jones, Charles C. (Cincinnati).- "Report of a Case of Fatal Epistaxis Following Varicella," p. 101.

Laessle, H. A. (Philadelphia).--"Nasaỉ and Pharyugeal Serquelæ of Influenza," p. 103.

Murphy, J. W. (Cincinnati).-. "Report of Removal of Foreign Bodies from the Bronchi and Esophagus," 1. 106.

This article does not lend itself to abstract.

Jackson, Chevalier (Philadelphia).--Editorial Department, p. 110.

Trans. Amer. Laryn., Rhin. and 0tol. Soc., 1917, University of Iowa Monographs, vol. i, No. 3. (Abstracted by J. K. Milne Dickie.)

Dean, L. W., and J. B. GRbgG (Iowa City)... "Report of a Case of Co-existent Carcinoma, Tuberculosis, and Syphilis of the CEsophagus."

\title{
OBITUARY.
}

\section{Dr. Clakence John Blake, Boston, U.S.A.}

WE regret to aunounce the death, on January 29 last, of Dr. Clarence John Blake, well known as probably the foremost American otologist of his time.

Born nearly seventy-six years ago, Dr. Blake received his medical education at Harvard Medical School, where he graduated M.D. in 1865. 
After studying abroad, and particularly in Vienna, where he received the O.M. Degree, he returned to Boston, and became lecturer at his old medical school, where in 1888 he was made Professur of Otology, a Chair which he occupied with approbation until 1913, when, on resigning the appointment, he was made Emeritus Professor.

From 1879 until 1882 Dr. Blake edited the American Journal of Otology, in addition to which he wrote a book on "Operative Otology," together with many articles in medical and other journals on his particular branch of medicine. In the midst of these professional activities he also found time to take a prominent interest in educational and other public work.

Dr. Blake was twice married, and it will be an added sorrow to those who had met Dr. and Mrs. Blake in recent years to learn that she also has recently died.

Prof. Urban Pritchard writes:

"I was deeply grieved to hear of the death of my old friend, Dr. Clarence Blake.

"Like all of us in this country, I had very great respect for him, both on account of his valuable work in otology and for his sterling character.

"His writings are too well known to require any mention by me, but I would like to remind my colleagues of his connection with the invention of the telephone. Dr. Graham Bell comsulted him on the physiological aspects of the work, and, when the company was formed to carry out the invention, the directors offered Dr. Blake a valuable post as adviser, but he was far too keenly interested in medicine to give it up for such a post.

"I was always struck by his keenness for work, his conscientiousness, and moreover by his extreme accuracy, so that one could absolutely depend on everything he stated.

"Prof. Clarence Blake was President of the International Otological Congress in Boston, which he made a great success. He was very anxious that these Congresses should continue to flourish, and a few weeks ago I had a letter from him urging the importance of the International Otological Congress re-assembling soon after the war was over.

“ 55, Wimpole S'Treet ;

"Urban Pritcharid.

"March 7, 1919."

\section{JAMES MaCkenzie Booth, M.D.,}

Aberdeen.

Br the death of Dr. Mackenzie Booth, of Aberdeen, our speciality has lost a worthy representative of the older school, and the general circle of medicine in Scotland has lost a striking and charming personality.

Mackenzie Booth was an Aberdonian, having been born in the granite city in 1855. Here he received his scholastic and medical education, graduating M.A. in 1875, M.B., C.M. in 1877, and M.D. in 1888.

After spending some time in Vienna, he settled down in 1880 in his native city, being made Surreon to the Ear and Throat Department of the Aberdeen Dispensary. Thereafter he became University Lecturer on Diseases of the Ear, Nose and Throat, but drifted into general surgery as years went on, with the appointments as Surgeon and Lecturer on Clinical Surgery to the Aberdeen Infirmary.

He earned for himself a position in our speciality which secured for him the secretaryship of the Otological Section of the British Medical Association Meeting in Newcastle-on-Tyue in 1892, and until his last 